\title{
Infeksjoner oppstått utenfor sykehus
}

\author{
Det engelske uttrykket community-acquired infection bør oversettes med infeksjon oppstått utenfor sykehus.
}

Infeksjoner kan deles i to grupper etter hvor man har pådratt seg dem. Infeksjoner som man smittes med i sykehus, kalles nosokomiale, men det er mye vanligere å bli infisert utenfor sykehus, noe som de siste årene er blitt omtalt som samfunnservervede infeksjoner (1).

Ordet nosokomial har en lang historie i norsk medisin. Det kommer fra gresk nosos (sykdom), og danner opphav til bl.a. nosologi (sykdomslære) og zoonose (sykdom som kan smitte fra dyr til menneske). Det andre begrepet, samfunnservervet, er et nyord på norsk.

\section{Samfunnservervet}

I det digitale Nasjonalbiblioteket (bokhylla.no) gir ordet samfunnservervet 14 treff, første gang i boken Medisinsk mikrobiologi fra 2000 (2). I tillegg til å være nytt, er det også lite brukt. I Retriever, en søketjeneste for aviser, tidsskrifter og andre publikasjoner, gir det kun ett treff, i 2007. I Tidsskriftets nettutgave er samfunnservervet kun registrert to ganger (3). Det brukes ikke utenfor fagmiljøet - det gir ingen treff i ordnett.no, som er Kunnskapsforlagets store ordboksamling.

I en vitenskapelig artikkel fra 2013 brukes uttrykket to ganger, men begge ganger skriver forfatterne «såkalt (min kursivering) samfunnservervet MRSA-smitte» (4). Det tyder på at også i fagmiljøet kan det oppfattes som nytt eller fremmed.

Opphavet er «community-acquired». På engelsk er det et veletablert uttrykk. I PubMed gir det nesten 17500 treff - første gang i 1973 (5). Det stemmer godt med opplysningene i Oxford English Dictionary (6), som oppgir en artikkel fra 1972 som første eksempel: «Patients with clinically active nosocomial and community-acquired infections were listed on one form» (7).

\section{Oversettelse}

Community-acquired er altså et fagbegrep som i hvert fall har eksistert siden begynnelsen av 1970-årene. I de siste årene har man forsøkt å etablere en norsk term for det samme. Det er åpenbart et behov for et uttrykk også på norsk.

Ordet samfunnservervet er bygd opp på en logisk og fornuftig måte. At det lyder litt rart, kan jo skyldes at vi er uvant med det og at ervervet er et ord på retur i norsk (8). Men problemet er nok helst at det er ufor-

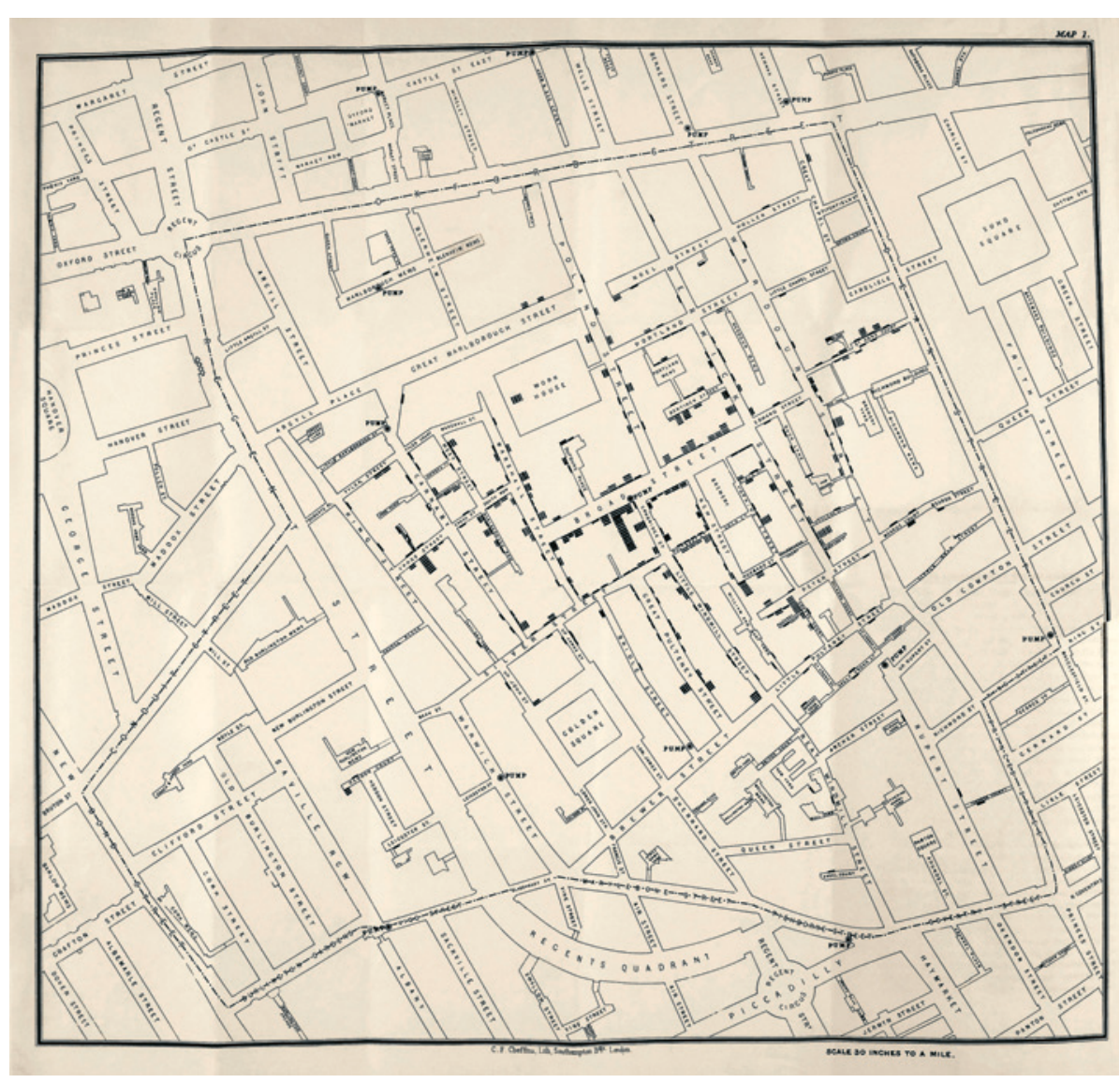

John Snows berømte kart over smitteveiene ved kolerautbruddet i London i 1854 - en «infeksjon oppstått utenfor sykehus». Illustrasjon: Science Photo Library

ståelig, det krever en forklaring for uinnviede. Det bidrar ikke til lesbarhet eller forståelse.

Oxford English Dictionary angir at community brukes i mange medisinske sammenhenger: community care, community health, community medicine, community hospital, community physician osv. (6). Ut fra disse eksemplene ville vi på norsk brukt samfunn om mange av dem, men samfunn passer ikke så bra i sammenheng med community-acquired infections. Dette er et eksempel på at en direkte oversettelse fra engelsk ikke alltid er den beste løsningen.

Motsatsen til samfunnservervet infeksjon er altså nosokomial infeksjon, som ifølge leksikonet er det samme som sykehusinfeksjon (9). Det er litt pussig, ettersom sykehusinfeksjoner omfatter mer enn navnet skulle tilsi, siden det også inkluderer infeksjoner oppstått ved sykehjem og tilsvarende helseinstitusjoner (10). Det svenske begrepet vårdrelaterade infektioner er derfor mer dekkende. Et alternativ på norsk kunne kanskje være iatrogene infeksjoner. På engelsk skiller man mellom hospital-acquired infections og det videre begrepet healthcare-associated infections.

\section{Konklusjon}

Vi vil foreslå at community-acquired infection ikke oversettes med «samfunnservervet infeksjon», men heller med infeksjon oppstått utenfor sykehus. Det er ikke mye lengre (31 versus 25 tegn), er dekkende og lett å forstå.

Jeg takker Petter Gjersvik for nyttige kommentarer.

\section{Erlend Hem}

erlend.hem@medisin.uio.no 
Erlend Hem (f. 1970) er dr.med., fagsjef i Klinikk psykisk helse og avhengighet, Oslo universitetssykehus, og redaktør for Tidsskriftets språkspalte.

\section{Litteratur}

1. Giæver P. Lungesykdommer. 3. utg. Oslo: Universitetsforlaget, 2015: 166-7.

2. Degré $M$, Hovig B, Bukholm $G$ et al, red. Medisinsk mikrobiologi. 2. utg. Oslo: Gyldendal Akademisk 2000.

3. Samfunnservervet. I: Tidsskrift for Den norske legeforening. http://tidsskriftet.no/articlesearch ?q=samfunnservervet $\&$ source $=$ mosez $(13.9 .2015)$

4. Steen TW, Jørgensen SB, Garder KM et al. MRSAfunn i sykehjem i Oslo 2005-11. Tidsskr Nor Legeforen 2013; 133: 1819-23.

5. Community acquired. I: PubMed.

www.ncbi.nlm.nih.gov/pubmed/?term $=\% 22$ community+acquired\%22 (13.9.2015).

6. Community. I: Oxford English Dictionary. http://public.oed.com/oederror404/ (13.9.2015).

7. Garner JS, Kaiser AB. How often is isolation needed? Am J Nurs 1972; 72: 733-7.

8. Ervervet. NB N gram. Nasjonalbiblioteket. www.nb.no/sp_tjenester/beta/ngram_1/\#ngram/ query?terms=ervervet $\&$ lang=all \&case_sens $=0 \&$ freq=rel\&corpus=bok (13.9.2015).

9. Kåss E. (13.2.2009). Nosokomial. I: Store medisinske leksikon. https://sml.snl.no/nosokomial (13.9.2015).

10. Schlichting E. (13.2.2009). Sykehusinfeksjon. I: Store medisinske leksikon. https://sml.snl.no/ sykehusinfeksjon (13.9.2015) 